\title{
NOD2 function in Crohn's disease
}

\author{
Alison Simmons
}

From 6th European Workshop on Immune-Mediated Inflammatory Diseases

Nice, France. 23-25 November 2011

\section{Abstract not submitted for publication}

Published: 23 November 2011

doi:10.1186/1479-5876-9-S2-I10

Cite this article as: Simmons: NOD2 function in Crohn's disease. Journal of Translational Medicine 2011 9(Suppl 2):110.

Submit your next manuscript to BioMed Central and take full advantage of:

- Convenient online submission

- Thorough peer review

- No space constraints or color figure charges

- Immediate publication on acceptance

- Inclusion in PubMed, CAS, Scopus and Google Scholar

- Research which is freely available for redistribution 